\title{
2022 Kuznets Prize Awarded to Luca Bonacini, Giovanni Gallo, and Sergio Scicchitano
}

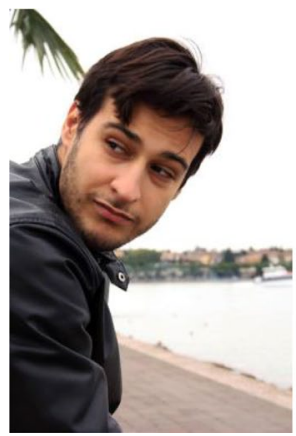

Luca Bonacini

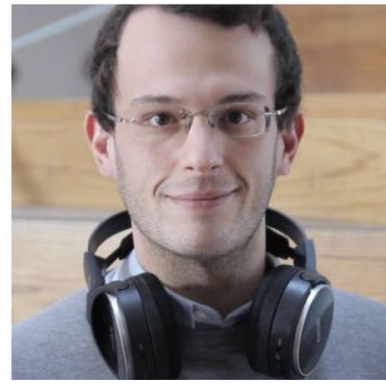

Giovanni Gallo

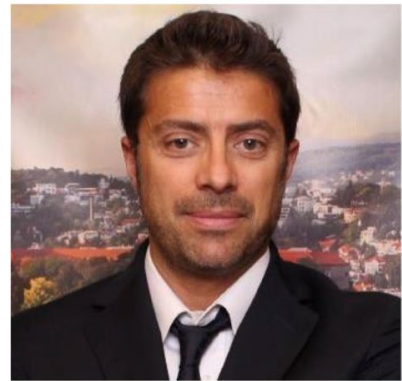

Sergio Scicchitano

Luca Bonacini (University of Modena and Reggio Emilia), Giovanni Gallo (Sapienza University of Rome), and Sergio Scicchitano (National Institute for Public Policies Analysis) have received the 2022 Kuznets Prize for their article "Working from home and income inequality: Risks of a 'new normal' with COVID-19", which was published in the Journal of Population Economics (2021), 34(1), pp. 303-360. The annual prize honors the best article published in the Journal of Population Economics in the previous year.

\section{Biographical abstracts}

Luca Bonacini is a postdoctoral research fellow at the University of Modena and Reggio Emilia. After a period of training internship at the Bank of Italy, he received his $\mathrm{PhD}$ in Labour, Development and Innovation at the University of Modena and Reggio Emilia in 2021. He was visiting scholar at the Luxembourg Institute for Socio-Economic Research and the University of Luxembourg. His main research interests focus on income distribution, social mobility, inequality in education, and gender inequality.

Giovanni Gallo is a postdoctoral research fellow at the Sapienza University of Rome since December 2020 and was previously at the National Institute for Public 
Policies Analysis (INAPP). He received his $\mathrm{PhD}$ at the University of Modena and Reggio Emilia in 2018. He was visiting scholar at the Tilburg University and the Luxembourg Institute for Socio-Economic Research (LISER), where he worked on financed research projects. His research interests include the evaluation of social policies, poverty, inequality, redistribution, household finance, and pensions. On these issues, he published in many international journals (e.g., Journal of Population Economics, Journal of Economic Behavior and Organization, Labour Economics).

Sergio Scicchitano is a Senior Researcher at the National Institute for Public Policies Analysis (INAPP), Rome, Italy. He obtained the National Scientific Qualification for the role of Associate Professor in Economic Policy. He is Co-Lead of the GLO "Coronavirus" thematic cluster and Section Editor for "COVID-19" in the current Handbook of Labor, Human Resources and Population Economics, 2020. He was Visiting Lecturer at the Queen Mary University of London and Adjunct Professor at the University "La Sapienza" of Rome, where he holds a Ph. D. in Economics. His fields of interest include applied econometrics, labor economics, COVID-19, and technological change. On these issues, he published in many international journals (e.g., Journal of Population Economics, Economic Modelling, Work Employment and Society).

\section{Abstract of the winning paper}

"In the current context of the COVID-19 pandemic, working from home (WFH) became of great importance for a large share of employees since it represents the only option to both continue working and minimize the risk of virus exposure. Uncertainty about the duration of the pandemic and future contagion waves even led companies to view WFH as a 'new normal' way of working. Based on influence function regression methods, this paper explores the potential consequences in the labor income distribution related to a long-lasting increase in WFH feasibility among Italian employees. Results show that a positive shift in WFH feasibility would be associated with an increase in average labor income, but this potential benefit would not be equally distributed among employees. Specifically, an increase in the opportunity to WFH would favour male, older, high-educated, and high-paid employees. However, this 'forced innovation' would benefit more employees living in provinces have been more affected by the novel coronavirus. WFH thus risks exacerbating pre-existing inequalities in the labor market, especially if it will not be adequately regulated. As a consequence, this study suggests that policies aimed at alleviating inequality, like income support measures (in the short run) and human capital interventions (in the long run), should play a more important compensating role in the future."

\section{About the Kuznets Prize}

The Journal of Population Economics awards the "Kuznets Prize" for the best paper recently published in the Journal of Population Economics. Starting from 2014, the Prize has been awarded annually. Papers are judged by the Editors of the Journal. 
Simon Kuznets, a pioneer in population economics, Professor Emeritus at Harvard University, and the 1971 Nobel Prize laureate in economics, died on July 10, 1985. Professor Kuznets was born in 1901 in Pinsk, Belarus, and came to the USA in 1922. He earned his Bachelor of Science in 1923, a Master of Arts degree in 1924, and his doctorate in 1926, all from Columbia University. During World War II, he was Associate Director of the Bureau of Planning and Statistics on the War Production Board, and he served on the staff of the National Bureau of Economic Research from 1927 to 1960 . Mr. Kuznets was a faculty member at the University of Pennsylvania for 24 years and Professor of Political Economy at Johns Hopkins University from 1954 until he joined Harvard University in 1960. He retired in 1971 and was given the title of George F. Baker Professor Emeritus of Economics. He was a former president of the American Economic Association and the American Statistical Association.

\section{Previous winners}

The Kuznets Prize has previously been awarded to:

2021: Yun Qiu (Jinan University), Xi Chen (Yale University), and Wei Shi (Jinan University) for their article "Impacts of social and economic factors on the transmission of coronavirus disease 2019 (COVID-19) in China", Journal of Population Economics, (2020), 33(4): pp. 1127-1172.

2020: Gautam Hazarika (University of Texas Rio Grande Valley), Chandan Kumar Jha (Le Moyne College, Madden School of Business), and Sudipta Sarangi (Virginia Tech) for their article "Ancestral ecological endowments and missing women”, Journal of Population Economics, 32(4): pp. 1101-1123.

2019: Yoo-Mi Chin (Baylor University) and Nicholas Wilson (Reed College) for their article "Disease risk and fertility: evidence from the HIV/AIDS pandemic," Journal of Population Economics, 31(2): pp. 429-451.

2018: Chunbei Wang and Le Wang (University of Oklahoma) for their article "Knot yet: Minimum marriage age law, marriage delay, and earnings," Journal of Population Economics, 30(3): pp. 771-804.

2017: Binnur Balkan (Stockholm School of Economics) and Semih Tumen (Central Bank of the Republic of Turkey) for their article "Immigration and prices: quasiexperimental evidence from Syrian refugees in Turkey," Journal of Population Economics, 29(3): pp. 657-686.

2016: Loren Brandt (University of Toronto), Aloysius Siow (University of Toronto), and Hui Wang (Peking University) for their article "Compensating for unequal parental investments in schooling," Journal of Population Economics, 28: 423-462.

2015: Haoming Liu (National University of Singapore) for his article "The quality-quantity trade-off: evidence from the relaxation of China's one-child policy", Journal of Population Economics, 27: 565-602.

2014: Paolo Masella (University of Essex) for his article "National Identity and Ethnic Diversity", Journal of Population Economics, 26: 437-454. 
Period 2010-2012: Richard W. Evans (Brigham Young University), Yingyao Hu (Johns Hopkins University) and Zhong Zhao (Renmin University) for their article "The fertility effect of catastrophe: US hurricane births", Journal of Population Economics, 23: 1-36.

Period 2007-2009: Makoto Hirazawa (Nagoya University) and Akira Yakita (Nagoya University) for their article "Fertility, child care outside the home, and payas-you-go social security”, Journal of Population Economics, 22: 565-583.

Period 2004-2006: Jinyoung Kim (Korea University) received the Kuznets Prize for his article "Sex selection and fertility in a dynamic model of conception and abortion," Journal of Population Economics, 18: 041-067.

Period 2001-2003: Olympia Bover (Bank of Spain) and Manuel Arellano (CEMFI), for their article "Learning about migration decisions from the migrants: Using complementary datasets to model intra-regional migrations in Spain", Journal of Population Economics, 15:357-380.

Period 1998-2000: David C. Ribar (The George Washington University), for his article "The socioeconomic consequences of young women's childbearing: Reconciling disparate evidence", Journal of Population Economics, 12: 547-565.

Period 1995-1997: James R. Walker (University of Wisconsin-Madison), for his article "The effect of public policies on recent Swedish fertility behavior", Journal of Population Economics, 8: 223-251.

Publisher's note Springer Nature remains neutral with regard to jurisdictional claims in published maps and institutional affiliations. 